\title{
Transcriçóes e notas
}


O Comitê Executivo do Projeto FLORAM, em reunião realizada no dia 21 de fevereiro, decidiu submeter os primeiros documentos do Projeto à apreciação crítica de 100 personalidades brasileiras da área técnico-científica de florestas e aos membros da comunidade ambientalista do País.

Este mesmo Comitê, em reunião recente, resolveu publicar nesta edição especial, sob forma de anexo, as observaçóes feitas por esses especialistas, demonstrando, com isso, a transparência de uma plataforma, em processo de elaboraçáo, através de aproximaçóes sucessivas.

Também foram incluídas como anexo algumas colaboraçóes e transcriçóes julgadas esclarecedoras. 